\title{
KEPEMIMPINAN PENDIDIKAN ISLAM DALAM PERSPEKTIF INTERDISIPLINER
}

\author{
Hifza, Muhamad Suhardi, Aslan, Silvia Ekasari \\ Institut Agama Islam Sultan Muhammad Syafiuddin Sambas \\ Hifzahamdan@yahoo.co.id \\ Universitas Pendidikan Mandalika Indonesia \\ ardhysmart@gmail.com \\ Institut Agama Islam Sultan Muhammad Syafiuddin Sambas \\ aslanmarani88@yahoo.com \\ Sekolah Tinggi Ilmu Ekonomi Manajemen Bisnis Indonesia Depok, \\ Silvia.ekasari@stiembi.ac.id
}

\begin{abstract}
Abstrak
Perkembangan teknologi seiring dengan perubahan sosial yang dialami masyarakat, maka kepemimpinan ikut juga menghadapi tantangan sesuai dengan tantangan dari perkembangan teknologi tersebut. Penelitian ini adalah penelitian literatur dengan mengkaji beberapa literatur untuk menemukan permasalahan dari kajian yang ingin dibahas. Hasil penelitian yang dilakukan, maka temuan dalam penelitian adalah; Pertama, kepemimpinan dari perspektif sosiologis adalah kepemimpinan yang mempunyai tantangan demi tantangan sesuai dengan perkembangan teknologi. Untuk menghadapinya, maka sebagai pemimpin perlu menerapkan sistem AGIL dengan memegang nilai-nilai prinsip dalam Islam. Kedua, kepemimpinan dari perspektif politik adalah pemimpin yang mempunyai tantangan dengan individu, lembaga, organisasi, partai dan lembaga lainnya sehingga untuk menghadapi tantangan tersebut adalah menyiapkan tantangan dari persyaratan tersebut dan bersaing secara sehat tanpa mengharapkan bantuan dari luar atau money politik.
\end{abstract}

Kata Kunci: Kepemimpinan, Pendidikan Islam, Sosiologis, Politik

\begin{abstract}
Technological progress will have an impact on social changes in society. Along with these advances, the challenges of leadership has also changed in the face of these technological changes. This study tried to examine various literatures related to leadership, politics and technological challenges in an effort to find the problems of the study to be discussed. Then the findings were as follows; First, leadership from a sociological perspective is leadership that faces challenges in accordance with technological developments. To deal with it, then as a leader it is necessary to implement the AGIL system by holding principles in Islam. Second, leadership from a political perspective is a leader who has challenges with individuals, institutions, organizations, parties and other institutions so that in facing these challenges, all leaders need to prepare themselves to face the challenges of these requirements and compete in a healthy manner without expecting outside help or political money.
\end{abstract}

Keywords: Islamic education, Leadership, Politics, and Sociology 



\section{PENDAHULUAN}

Manusia dalam kehidupannya tidak terlepas dari perubahan. Dampak dari perubahan tersebut disatu sisi mempunyai dampak yang positif, disisi lain mempunyai dampak yang negatif. Dalam hal ini, setiap perubahan maka akan diikuti oleh perubahan lainnya, baik sosial, budaya, ekonomi dan juga politik, termasuk dalam hal kepemimpinan. Kepemimpinan erat kaitannya dengan golongan, yang mana kelompok golongan tersebut dipimpin oleh seseorang yang bisa untuk dipertanggung jawabkan, misalnya kepemimpinan kepala sekolah dalam membawahi bawahannya. Intinya kepemimpinan adalah seseorang yang memimpin bawahannya, baik itu dalam lembaga pendidikan, perusahaan, organisasi politik dan organisasi lainnya.

Pemimpin mempunyai karakteristik tersendiri yang setiap lembaga dari kepemimpinan mempunyai tipe-tipe pemimpin yang berbeda, ada yang disenangi, dihormati, disegani dan tidak dihargai, tetapi pemimpin yang selalu diinginkan oleh setiap orang adalah pemimpin yang dihormati dan bukan disegani, sehingga pemimpin yang dihormati secara otomatis akan dihargai maupun disegani. Begitu juga halnya, dengan pemimpin yang disegani tetapi tidak dihormati, maka berarti bawahannya hanya takut kepadanya sehingga pemimpin tidak mempunyai wibawa sama sekali, karena dampak pemimpin seperti ini hanya dihormati di era masanya menjadi pemimpin, tetapi ketika telah selesai menjabat menjadi pemimpin maka sama sekali tidak dihormati, bahkan dihargai sama sekali.

Penghargaan dari nama seorang pemimpin selalu dikenang, walaupun sudah tiada, sehingga ada sebuah stigma, dengan ungkapan "setiap pemimpin ada masanya dan setiap masa ada pemimpinnya"(Zamzam, 2018). Masa kepemimpinan adalah masa sejarah dimana pemimpin mempunyai karakteristik sendiri dalam dirinya sehingga diingat sampai sekarang, sehingga Sztompka, memberikan perubahan tidak terlepas dari sejarah. Periodesasi sejarah itu juga telah dipetakan oleh ahli sosiologi dari Amerika sekaligus pengamat masa depan yang dikenal sebagai Alvin (Toffler, 1970, pp. 1-3) (Toffler, 1980), memetakan perubahan yang dialami oleh melalui tiga fase, yakni fase pertanian, industri dan masa sekarang yang dikenal sebagai informasi.(Mujiburrahman, 2017) Era informasi yang dialami manusia saat ini, maka manusia hidup diantara dua dunia, yakni dunia alam nyata seperti yang kita alami saat ini dan alam maya, sebagaimana hadirnya kita di media sosial dengan telepon ponsel pintar yang kita miliki. Akan tetapi, hadirnya dua alam dunia pada kehidupan manusia saat ini, ternyata manusia lebih banyak hidup di alam dunia maya. Di manamana manusia selalu ada, baik melalui 
komentar dalam faceebok, instragram, foto yang selalu di upload di media sosial dan media lainnya. Bahkan, dalam hitungan satu menit manusia di alam dunia maya bisa menampilkan tempat yang berbeda-beda dengan lokasi yang sama atau tempat yang beda dengan lokasi yang beda. Pengaruhpengaruh sosial itulah yang dialami masyarakat saat ini, mempunyai tantangan yang begitu besar, yang bukan hanya tantangan secara pribadi, keluarga, masyarakat tetapi juga tantangan dalam kepemimpinan.

Pemimpin sama juga halnya dengan internet yang mempengaruhi manusia untuk setiap saat terbuai dalam pelukannya, sementara kepemimpinan harus bisa mempengaruhi sebuah lembaga atau organisasi yang dipimpinnya (Syafaruddin, 2005, pp. 156-157). Pemimpin yang bisa mempengaruhi orang lain, maka menggunakan berbagai macam cara, seperti menggunakan otoritas yang terlegitimasi, menciptakan model atau menjadi teladan, penetapan sasaran, memberi imbalan dan hukuman, restrukrisasi organisasi, dan mengkomunikasikan sebuah visi.(Teguh, dkk, 2001, p. 69)

Menurut Ordway Tead dalam (Mujiono, 2002, p. 18), seseorang yang bisa menjadi pemimpin karena beberapa sebab, diantaranya; organisasi yang dimilikinya, dipilih oleh golongan dan ditunjuk dari atasan. Setelah menjadi pemimpin, maka jiwa kepemimpinan biasanya timbul sendiri atau setelah menjadi pemimpin. Namun, hal yang paling berpengaruh seseorang menjadi pemimpin adalah tipe kepemimpinan yang dimilikinya.

Tipe-tipe kepemimpinan dapat dikelompokkan menjadi kepemimpinan tradisional, transaksional, kharismatik, transformasional, dan kepemimpinan spiritual, (Karim, 2010, p. 4) (Ivancevich, dkk, 2007, p. 211) (Danim, 2003, p. 53) (Widodo, n.d.) kreatif, (Langgulung, 1991, p. 45) (Hendro, 2011, p. 74)inovatif dan tipetipe kepemimpinan lainnya (McClelland, D, 1987, p. 165) (Bass, B. M, 1990, p. 74) Tipe dari gaya kepemimpinan adalah sebuah perbedaan dari latar belakang yang dimilikinya.(Kartono, 1984, p. 34)

Tipe-tipe kepemimpinan tersebut, sesuai era dan masanya akan mengalami perubahan sesuai dengan dampak perubahan sosial yang dialami masyarakat sehingga berimbas juga untuk menjadi seorang pemimpin dalam sebuah lembaga. Manusia saling menginginkan untuk mencapai kekuasaan, tanpa lagi mengindahkan agama yang dimilikinya, sehingga manusia dalam berpolitik telah menghalalkan berbagai cara, dengan tidak lagi memandang yang halal maupun haram, yang penting bisa berkuasa. Dampakdampak dari perubahan sosial dalam kepemimpinan mengalami perubahan yang luar biasa, seiring dengan perkembangan 
politik yang dialami manusia. Dalam hal inilah, penulis merasa tertarik untuk menelaah lebih jauh tentang kepemimpinan pendidikan Islam dalam perspektif interdisipliner, dengan lebih menjuruskan pada kajian sosiologis dan politik.

\section{KAJIAN TEORI}

\section{Kepemimpinan Pendidikan Islam}

Perubahan yang dialami manusia dari masa ke semasa yang mana setiap masa budaya yang dialami manusia ikut mengalami pembaharuan. Bahkan, modernisasi dari teknologi setiap tahunnya membawa perubahan yang besar dengan dampak perubahan yang begitu berarti. Disatu sisi mempunyai dampak positif, disisi lain membawa dampak negatif yang mana dampak tersebut telah membawa kepemimpinan memiliki dua cabang, yakni pemimpin yang tidak lagi mengindahkan agama Islam dan pemimpin yang masuk berkuasa sesuai koridor Islam.

Kepemimpinan adalah seni untuk mempengaruhi orang lain, baik mempengaruhi individu, organisasi atau lembaga agama, pendidikan, lembaga masyarakat, maupun lembaga-lembaga lainnya. Pemimpin adalah seseorang yang bisa memanejeman, baik untuk dirinya, orang lain maupun organisasi yang dipimpinnya (Ramli, 2017) (Rivai \& Mulyadi, 2003, p. 2). Manajemen yang paling utama adalah menajemen diri. Orang yang mampu memanejemen dirinya dari segi waktu maka pada saat dia menjadi pemimpin, maka waktu adalah uang. Waktu digunakan dengan sebaik-baiknya sehingga membawa manfaat bagi dirinya. Dampak perubahan sosial, misalnya di dunia kerja yang saat ini telah dihadirkan finger print dengan waktu masuk sekian dan jam pulang sekian adalah merupakan alat mendeteksi kehadiran seseorang, yang mana jika tepat waktu maka mendapatkan materi sesuai dengan perjanjian. Padahal, hakikat dari kebenarannya, alat ini adalah sebagai nilai materi sehingga nilai-nilai spiritual tidak lagi dipikirkan(Fauzi, 2017; Khoiri, 2016). Orang masuk dengan tepat waktu, tetapi setelah finger print, orangnya pergi kemana-mana, ada yang pergi ke pasar, jalan-jalan dan lain sebagainya, sehingga masuknya awal tetapi sebenarnya kerjanya tidak ada. Hal seperti inilah, sebenarnya tidak sesuai dengan prinsip nilai-nilai Islam, lebih-lebih lagi menyangkut tentang kepemimpinan.

Pemimpin yang amanah maka akan menjadi nilai keteladanan bagi orang lain. Begitu juga dengan sebaliknya. Karakterkarakter seperti inilah yang sebenarnya dikatakan sebagai pemimpin, karena kepribadiannya yang baik dapat mempengaruhi orang lain yang ada di sekitarnya.(Kartono, 1984, p. 181) Kepemimpinanannya telah mampu menghasilkan sumber daya manusia yang berakhlak kharimah sesuai dengan prinsip 
Islam.(Hutagaluh \& Aslan, 2019) Pengaruh kepemimpinannya bukan hanya terikat oleh jabatan dan kedudukan yang dimilikinya, tetapi kepemimpinannya menjadi contoh bagi keteladanan masyarakat, sehingga mendapat pengakuan bagi masyarakat.(Ahmadi, 2002) Kepemimpinan sesuai dengan prinsip Islam adalah pemimpin yang adil, arif, bijaksana, sabar, sederhana dan sifat-sifat terpuji lainnya.(Mahmuddin, 2014)

Dengan demikian, kepemimpinan adalah kecakapan seseorang yang dimilikinya, yang mempunyai perbedaan dari pemimpin yang lain. Perbedaan karakter tipe-tipe kepemimpinan seperti inilah, sehingga tipe dan gaya kepemimpinan mempunyai perbedaan juga, yang bukan hanya tipe kepemimpinannya dari jabatan dan kedudukan yang dimilikinya, tetapi tipe kepemimpinan yang ada pada dirinya. Sementara, kepemimpinan pendidikan Islam adalah seseorang yang bukan hanya menjadi pemimpin bagi lembaga Islam, seperti di sekolah, tetapi seorang pemimpin yang bisa menjadi teladan bagi orang lain dari kepribadian nilai-nilai akhlak positif yang dimilikinya dengan menerapkan prinsipprinsip dalam Islam(Aprilianto \& Mariana, 2018).

\section{METODE PENELITIAN}

Penelitian ini menggunakan studi kepustakaan (library research) yang memusatkan perhatian pada isu-isu penting seputar kepemimpinan pendidikan Islam, dengan tinjauan sosiologis dan politik. Teknik pengumpulan data dilakukan dengan mengidentifikasi wacana dari buku-buku, makalah atau artikel, majalah, jurnal atau informasi lain untuk mencari hal-hal berupa catatan, transkrip, buku, dan lain sebagainya yang berkaitan dengan kepemimpinan dalam Islam.

Adapun, cara-cara dalam pengumpulan data kajian dokumen ini adalah; Pertama, melakukan kajian kepustakaan yang sesuai dengan bahan yang ingin diteliti. Kedua, setelah data didapatkan, maka akan dianalisis melalui data metode deskriptif sesuai dengan pemahaman penulis.(Aslan, 2017)

\section{HASIL DAN PEMBAHASAN}

Al-Qur'an dah hadis Nabi yang merupakan sumber hukum Islam, bukan hanya berbicara tentang masalah hukum di masyarakat, tetapi mencakup esensi yang begitu luas, baik yang telah terjadi maupun yang belum diketahui sama sekali oleh manusia. Oleh karena itu, setiap apapun yang terjadi yang dialami manusia adalah merupakan bagian dari ajaran Islam termasuk dalam politik. Selain itu juga, setiap dampak perubahan yang dialami 
masyarakat, maka diikuti perubahan lainnya, termasuk dalam hal kepemimpinan.

Kepemimpinan pendidikan Islam dalam tinjauan sosiologis adalah melihat seorang pemimpin mengalami transformasi dari dampak gejala perubahan sosial yang dihadapinya. Jika pemimpin masih menerapkan tipe-tipe kepemimpinan tanpa mengikuti arus modernisasi, maka pemimpin seperti itu tidak akan mampu menjawab tantangan zaman. Pemimpin hanya dihormati di waktu tertentu, tetapi tidak dikenali di waktu yang lain.

Kepemimpinan terjemahan kata dari leadhership. Kepemimpinan dan pemimpin adalah beda dari pengertiannya. Pimpinan adalah tugasnya memimpin sehingga pimpinan disebut sebagai manajer. Kepemimpinan adalah bakat atau sifat yang dimiliki oleh manajer tersebut. (Mahmuddin, 2014) (Fitriani, 2015). Dalam bahasa Indonesia, pemimpin disebut juga sebagai "penghulu, pemuka, pelopor, pembina, panutan, pembimbing, pengurus, penggerak, ketua, kepala, penuntun, raja, tua-tua dan sebagainya". Kata pemimpin artinya memberikan bimbingan.(Ma'sum, 2019) Dari pengertian tersebut, maka kepemimpinan mempunyai pengertian yang sama tetapi cakupan yang berbeda dari kepemimpinan yang dilaksanakannya, baik dalam hal lembaga pendidikan, organisasi maupun partai.
Kepemimpinan yang tidak mengalami perubahan dari pengertiannya, tetapi mengalami perubahan tipe-tipe kepemimpinan yang pernah diembannya, misalnya dalam lembaga pendidikan Islam di pondok pesantren. Sejak dahulu, kepemimpinan pondok pesantren tidak terlepas dari seorang kyai. Kiai memainkan peranan penting bagi kepemimpinanannya di pondok pesantren yang dibangunnya. Akan tetapi, paradigma kepemimpinan mengalami perubahan seiring dengan perubahan sosial sekaligus politik kepemimpinan yang dilaksanakannya di pondok tersebut.

Kiai yang memimpin di pondok pesantren dikenal sebagai pemimpin kharismatik (Ramli, 2017) (Kesuma, 2014). Saat ini, seiring perkembangan teknologi, pemimpin kharismatik yang dimiliki kiai mengalami perubahan. Kepemimpinan kiai dianggap sebagai pemimpin rasional dengan ilmu yang dimilikinya sehingga kharismatik melekat pada diri kiai.(Syatibi, 2009) Selain itu juga, banyak contoh-contoh lain dari kepemimpinan pendidikan Islam yang mengalami perubahan dari dampak teknologi saat ini.

Oleh karena itu, perubahan adalah niscaya, jika tidak seorang pemimpin melakukan kolaborasi kepemimpinan, seperti halnya kepemimpinan dalam mengasuh anak di era digital, dengan menerapkan beberapa pola asuh anak yang 
sesuai dengan prinsip-prinsip Islam.(Aslan, 2019) Jika, kepemimpinan hanya sekedar menghadapi tantangan zaman, tanpa memperhatikan nilai-nilai Islam, maka banyak akan melahirkan pemimpin yang tidak menghargai waktu, pemimpin yang korupsi, pemimpin yang tidak amanah, tidak berakhlak, menghalalkan berbagai macam cara dan pemimpin yang tidak mempunyai karakter yang baik dan pemimpin dengan nilai-nilai negatif lainnya.

Menurut Abdul Kadir,(Kadir, n.d.) pemimpin yang sesuai dengan tipe kepemimpinan saat ini adalah pemimpin ulul albab. Tipe kepemimpinan ini memiliki tiga prinsip, yakni zikir, fikir dan amal shaleh. Jika seorang pemimpin yang memiliki tingkat zikir yang tinggi, serta melakukan fikir yang mendalam, sehingga dorongan untuk melakukan amal shaleh yang besar, maka pemimpin seperti itu memiliki kepemimpinan ulul albab yang tinggi disisi Allah (Ma'arif \& Rofiq, 2019). Tipe kepemimpinan ulul albab merupakan salah satu prinsip kepemimpinan dalam Islam, tetapi jika pemimpin ulul albab tidak kreatif, inovatif dan proaktif, maka kepemimpinan yang dimilikinya tidak akan mampu untuk menjawab tantangan zaman. Kepemimpinannya tidak mampu bertahan dari arus globalisasi saat ini, lebih-lebih lagi kepemimpinan yang mendidik generasi milineal saat ini, yang mana tenaga pendidik akan mengalami ketertinggalan jika tidak maju selangkah dari anak didik yang hidup di era digital saat ini. Anak didik bisa menjawab pertanyaan dari tenaga pendidik dengan berbagai perspektif jawaban, tetapi tenaga pendidik, bukan hanya menjawab dengan berbagai perspektif tetapi bisa menjadi penengah dari jawaban yang diinginkan oleh anak, misalnya perbedaan dalam masalah agama saat ini.

Oleh karena itu, kepemimpinan dari pengertian sosiologis bukanlah semacam makna al-Qur'an dan hadis dari makna teks tetapi konteks, yang mana keberlangsungan kepemimpinan tersebut tidaklah terlepas dari politik. karena pengertian politik adalah luas, yang bukan berbicara masalah partai, pemerintahan, tetapi juga berbicara masalah individu seseorang, termasuk dalam hal kepemimpinan dari nilai karakter yang ada pada dirinya.

\section{Kepemimpinan Dalam Perspektif Sosiologis}

Kepemimpinan dari tinjauan sosiologis adalah dampak perubahan sosial yang dialami oleh masyarakat, dari teknologi yang sederhana sampai modern, sehingga makna, tujuan dan fungsi kepemimpinan ikut juga mengalam perubahan.

Perubahan yang dialami oleh masyarakat, maka segala aspek dalam kehidupan masyarakat ikut juga berubah, baik aspek sosial, budaya, ekonomi, politik, ilmu pengetahuan dan teknologi (Hanifah 
Gunawan, Karim Suryadi dan Elly Malihah, n.d.) (Xiong, 2009). Sebagai hal contoh, kepemimpinan orang tua dalam memimpin keluarganya. Sebelum adanya penitipan anak, maka orang tualah yang mengasuh anaknya, sehingga keseharian orang tua, selalu bersama anak-anak. Kemudian, dampak dari perubahan sosial, maka pola asuh orang tua pun mengalami perubahan.

Orang tua disibukkan dengan bekarja sehingga anak-anak dititipkan di penitipan anak-anak. Bahkan, orang tuanya pun dititiptkan di panti asuhan jompo (Moh. Padil \& Triyo Supriyatno, 2010) (Damsar, 2011). Pola asuh orang tua lebih menekankan kasih sayang dengan pemenuhan kebutuhan barang-barang teknologi, dibandingkan kasih sayang sejati,(Aslan, 2019) sehingga dampak yang dihasilkan anak-anak banyak mengkonsumsi jaringan-jaringan dari sumber teknologi dibandingkan kasih sayang orang tua. Dalam hal inilah, dampak perkembangan teknologi segala-galanya telah mengubah kehidupan di masyarakat.

Teknologi seperti pisau yang bermata dua, disatu sisi membawa manfaat yang luar biasa, tetapi disisi lain membawa mudharat yang luar biasa juga.(Mujiburrahman, 2017) Fase-fase perkembangan teknologi yang dimulai dari tulisan tangan, ditemukan mesin cetak, media audio visual, media audio, masingmasing perkembangan teknologi tersebut mempunyai dampak yang berbeda-beda, lebih-lebih lagi dampak yang dihasilkan oleh perkembangan teknologi sekarang yang dikenal dengan informasi.(Mujiburrahman, 2015) Informasi dengan kecanggihan teknologi telah membuat masyarakat konsumtif dan menuhankan barang-barang teknologi.(Mujiburrahman, 2016) Manusia sudah materialistis dan gaya kehidupan manusia sudah ke arah hedonis(Kirgiz, 2014) (Zulkifli, 2016) (Aslan et al., 2019). nilai-nilai positif dalam bertingkah laku di masyarakat, ikut juga berubah, misalnya norma yang dimiliki masyarakat, tingkah laku, interaksi sosial dan fenomenafenomana kultural.(Fatma Melati, 2013) Gejala-gejala negatif yang ditimbulkan teknologi begitu banyaknya, walaupun mempunyai keseimbangan dari dampak positif yang dimilikinya, yang mana hal ini sebenarnya tergantung dari manusia dalam memanfaatkan teknologi tersebut. Teknologi adalah sebagai alat yang tidak bisa berjalan dengan sendirinya jika tidak dioperasikan oleh manusia.

Menurut Yasraf Amir (Piliang, 2011) era informasi saat ini, seolah-olah dunia telah dilipat. Manusia untuk mengetahui informasi dari mana saja hanya bermodalkan ponsel pintar yang dimilikinya. Jumlah bukubuku yang tersimpan di rak buku, semuanya tersimpan dalam flash disk dan kemudahankemudahan lainnya. 
Thomas L. Friedman, mengatakan bahwa dampak perkembangan yang begitu pesat saat ini, kepemimpinan bukan menghadapi tantangan dari internal, ekternal, tetapi mendapatkan ancaman dari situasi internet. Internet bukan hanya terdapat diperkotaan tetapi telah menjalar di pedesaan (Nukman, 2014) (Putri Ekasari dan Arya Hadi Dharmawan, 2012).

Dengan demikian, sejarah perjalanan teknologi tersebut, telah mengubah paradigma dalam jiwa kepemimpinan seseorang. Syarat kepemimpinan semakin besar, pendidikan formal menjadi priroritas, orang kaya semakin berpengaruh, orang miskin semakin terjajajah. Kepemimpinan dalam Islam ikut juga mengalami perubahan. Syarat kepemimpinan, misalnya di lembaga pendidikan formal tidak lagi berdasarkan keturunan atau zuriat, tetapi banyak faktor yang dipertimbangkan.

Diantara syarat yang dimiliki oleh seorang pemimpin, diantaranya; memiliki pendidikan, kemampuan berkembang secara mental, ingin tahu, kemampuan analistis, memiliki daya ingat yang begitu kuat, integratif, kemampuan berkomunikasi, keterampilan mendidik, rasionalitas dan obyektivitas, pragmatis, sense of urgency, sense of timing, sense of cohesiveness, sense of relevance, kesederhanaan, keberanian, kemampuan mendengar, adaptabelitas dan fleksibilitas dan ketegasan.(Mahmuddin, 2014)
Oleh karena itu, kepemimpinan Islam tinjauan sosiologis adalah kepemimpinan yang mempunyai tantangan, yang mana tantangan tersebut mempunyai perbedaan dari kepemimpinan sebelumnya. Setiap tantangan dari dampak perubahan sosial dari teknologi tradisional sampai teknologi modern, maka melahirkan tipetipe kepemimpinan yang berbeda-beda. Namun, dalam konsep Islam, kepemimpinan yang sesuai dengan nilai Islam adalah kepemimpinan yang tidak terlepas dari koridor-koridor ajaran Islam(Rosyad \& Maarif, 2020).

Menurut Talcott ( Parsons \& Smelser, 2005, p. h. 46-50) (Thomas J. Fararo, 2006)Sztompka, 1993, p. 3) menciptakan teori dari perkembangan masyarakat yang dikenal dengan AGIL, dengan singkatan Adaptation, Goal attainment, integrasi dan latency. Teori ini jika dikaitkan dengan kepemimpinan dalam menghadapi tantangan sosial, maka teori ini dianggap cocok di zaman sekarang. Teori Agil mempunyai singkatan dengan makna (A) adalah adaptasi terhadap lingkungan, $(G)$ Tujuan sistem pencapaian, (I) Integrasi dalam bagian sistem, (L) Pemeliharaan sistem nilai yang telah dilembagakan.

Dengan demikian, kepemimpinan harus bisa beradaptasi dengan lingkungannya, yang mana lingkungan di zaman sekarang mengalami perbedaan di zaman dahulu yang dikenal dengan 
Adaptation. Pemimpin harus mempunyai tujuan yang bukan hanya untuk kepentingannya sendiri tentapi membawa manfaat kepada masyarakat banyak, yang dikenal dengan Goal attainment. Kepemimpinan bukan hanya terbuai dengan perubahan zaman tetapi harus bisa menjawab tantangan zaman. Disatu sisi, kepemimpinannya menjadi nilai teladan bagi orang lain, yang mana teladan tersebut terintegrasi dari bawahan-bawahannya maupun yang dipimpinnya yang dikenal dengan integrasi. Segala-galanya dimasa kepemimimpinannya, maka nilai-nilai menjadi seorang pemimpin harus diutamakan yang sesuai dengan agama Islam, yang dikenal sebagai latency. Pemimpin yang menerapkan sistem AGIL, maka walaupun bagaimana dampak perubahan sosial yang dialami masyarakat, maka semakin besar dampak positif bagi dirinya sendiri, keluarga, agama, masyarakat, bangsa dan negara.

\section{Kepemimpinan Dalam Perspektif Politik}

Secara garis besar, politik diartikan sebagai sumber kekuasaan dari kepemimpinannya dalam partai politik (Nata, 2011, p. 316) (Setyadarmodjo, 2000). Semakin besar dampak perubahan sosial yang terjadi di masyarakat, maka peran politik semakin besar.(Rosana, 2011, p. 39) Masyarakat saling-saling ingin berpolitik untuk mendapatkan kekuasaan dalam
kepemimpinan.(Retnowati，2014) Berbagai macam segala cara selalu dilakukan agar mendapatkan kedudukan, materi sehingga menghalalkan berbagai macam cara, tanpa mengindahkan sama sekali etika dalam berpolitik.

Politik pada hakikatnya, agar sesuai dengan nilai-nilai Islam, maka dalam berpolitik tidak memaksa, menakut-nakuti dan perbuatan negatif lainnya.(Siswanto, 2007) Dari beberapa literatur yang penulis jelaskan adalah politik adalah kekuasaan dalam ruang lingkup lembaga, organisasi partai dan lembaga lainnya. Sumber kekuasaan adalah seorang pemimpin dalam memimpin bawahannya termasuk dirinya sendiri. Manusia dalam berpolitik disuatu organisasi mempunyai pandangan yang berbeda-beda dari tipe-tipe politik yang dilakukannya untuk mempengaruhi masyarakat.

Menurut Robert Lane dari hasil penelitiannya yang dikutip oleh Michael Rush Philip Althoff,(Althoff, 2015, p. 179) bahwa orang yang berpolitik memiliki tujuan sebagai sarana kebutuhan ekonomis, untuk memenuhi kebutuhan nafsu sosial, psikologis dan mendapatkan nilai-nilai khusus. Dilihat dari tujuan politik dari hasil penelitian Robert Lane, hampir sama juga dengan yang terjadi di perpolitikan di Indonesia untuk menjadi seorang dewan. Seorang dewan mampu menghabiskan jutaan rupiah, bahkan telah mencapai 
miliaran rupiah yang mana jika dewan tersebut telah jadi, maka uang yang hasil pengeluarannya menjadi dewan, maka dengan kekuasaan kedudukannya ia mampu menghabiskan anggaran aspirasi untuk keuntungannya tanpa membawa manfaat bagi masyarakat banyak. Untuk memenuhi kebutuhannya secara ekonomi dan psikologi, maka hasil-hasil barang teknologi yang dimilikianya selalu update dan hargaharga teknologi yang dimilikinya pun bernilai tinggi. Untuk mendapatkan nilai khusus, maka ia mampu menghabiskan uang demi menginginkan tujuannya tersendiri.

Prolog dari gambaran seorang pemimpin yang telah dicontohkan oleh orang penulis, telah banyak terjadi di perpolitikan di Indonesia, sehingga kepemimpinan dalam memperjuangkan kedudukan dan jabatannya ia mampu menghabiskan uang dan berani menghalalkan berbagai macam cara, walaupun bertentangan dengan agama yang dimilikinya.

Strata sosial semakin mengalami ketimpangan dari dampak perubahan sosial yang terjadi. Politik kehidupan masyarakat dari strata yang dimiliki, terdiri dari tiga kategori, yakni strata rendah, menengah dan atas. Strata rendah dimiliki oleh keluarga ekonomi rendah, seperti buruh, petani, pedagang kecil, karyawan dan formal pendidikannya pun rendah. Sementara, strata menengah meliputi standar ekonomi tinggi dengan gaji yang besar dan pendidikan yang dimiliki semakin tinggi. Adapun, strata sosial tinggi adalah adalah strata ekonomi atas, kara raya dan tidak khawatir untuk masa depan.(Idi, 2011, pp. 177-178) Strata sosial tinggi dihormati oleh strata sosial menengah dan rendah. Siapa yang memiliki strata tinggi, maka menjadi pemimpin bagi strata yang bawah, padahal dalam Islam yang menjadi perbedaan adalah takwanya.

Al-Qur'an jika dipahami secara tekstual, maka secara lengkap dan jelasnya tidak disebutkan tentang cara berpolitik, tetapi ide-ide tentang politik secara global, sebenarnya sudah disebutkan, tergantung dari manusia yang memahaminya. Menurut Ibn Khaldun, dengan adanya agama dalam suatu negara dapat memperikat solidaritas kelompok dan dengan adanya agama, maka negara semakin kuat (Makmur, 2013). Namun, solidiritas masyarakat mengalami dampak yang besar bagi perubahan masyarakat adalah mempunyai kesatuan yang sama.(Khotimah, 2014) Dari beberapa gambaran tentang politik dalam al-Qur'an dan hadis, sebenarnya telah dilakukan oleh Rasulullah tentang cara-cara Rasulullah berpolitik. Kemudian, cara-cara politik Rasulullah dipraktekkan oleh para sahabat, tabi'in, dan generasi-generasi seterusnya.

Sejarah dari politik di masa Islam, telah menoreskan sejarah yang begitu panjang.(Buchori, 2009, p. vii) Hal tersebut bisa dilihat dari bangunan sejarah yang 
sampai saat ini masih tetap terjaga dan dilestarikan, sehingga perubahan sosial disebut juga dengan pembangunan (Noor, 2010) (Yulifar, 2010). Sejarah tersebut bisa ditelusuri dari buku atau peninggalanpeninggalan pembangunan di masa kejayaan Islam yang sampai sekarang masih tetap dijaga, dilestarikan oleh beberapa negara, baik negara Timur dan Barat.

Dengan demikian, dampak perubahan yang dialami masyarakat, maka kepemimpinan juga menghadapi tantangan dalam berpolitik, baik politik secara pribadi, golongan, sekelompok, lembaga pendidikan formal, informal dan non formal maupun lembaga-lembaga lainnya. Jika kepemimpinan politik dilihat dari secara individu, maka tantangan yang dihadapinya adalah persaingan secara individu, misalnya dalam hal pekerjaan. Untuk mendapatkan pekerjaan di lembaga tertentu berbagai macam persyaratan, termasuk yang utama adalah pendidikan. Oleh karena itu, politik bagi diri sendiri adalah dengan cara pendidikan. Tantangan politik bagi diri sendiri adalah pendidikan. Ketika syarat utama sudah didapatkan, maka syarat selanjutnya adalah mengikuti aturan-aturan dari lembaga yang membuka lowongan dan jangan sampai main belakang atau sogokmenyogok. Jika kepemimpinan untuk memimpin lembaga organisasi dan politik, maka syarat utama yang diinginkan oleh pemerintah dan partai, maka kita hanya mengikuti persyaratannya, tanpa bermain belakang untuk mencapai kedudukan yang kita inginkan, karena perbuatan tersebut tidak sesuai dengan agama Islam. Politik pada hakikatnya adalah suci, tetapi yang membuatnya ternoda adalah manusia dalam berpolitik.

\section{KESIMPULAN}

Perubahan yang dialami masyarakat disatu sisi membawa dampak positif, tetapi disisi lain membawa negatif, termasuk dalam hal kepemimpinan. Setiap perubahan yang dialami manusia, maka kepemimpinan mempunyai tantangan, sebagaimana tantangan kehidupan manusia di zaman ia hidup. Semakin besar perkembangan teknologi, maka tantangan kepemimpinan semakin besar. Dari hasil penelitian diperoleh; Pertama, kepemimpinan dari perspektif sosiologis adalah kepemimpinan yang mempunyai tantangan demi tantangan sesuai dengan perkembangan teknologi. Untuk menghadapinya, maka sebagai pemimpin perlu menerapkan sistem AGIL dengan memegang nilai-nilai prinsip dalam Islam. Kedua, kepemimpinan dari perspektif politik adalah pemimpin yang mempunyai tantangan dengan individu, lembaga, organisasi, partai dan lembaga lainnya sehingga untuk menghadapi tantangan tersebut adalah menyiapkan tantangan dari persyaratan tersebut dan bersaing secara 
sehat tanpa mengharapkan bantuan dari luar atau money politik.

\section{REFERENSI}

Ahmadi, A. (2002). Psikologi Sosial. Rineka Cipta.

Althoff, M. R. P. (2015). Pengantar Sosiologi Politik, terj. Kartini Kartono. PT. Raja Grafindo Persada.

Aprilianto, A., \& Mariana, W. (2018). Permainan Edukasi (Game) Sebagai Strategi Pendidikan Karakter. Nazhruna: Jurnal Pendidikan Islam, 1(1), 139-158. https://doi.org/10.31538/nzh.v1i1. 47

Aslan. (2017). Pumping Teacher dalam Tantangan Pendidikan Abad 21. 2, nomor 2, 89-100.

Aslan. (2019). Peran Pola Asuh Orangtua di Era Digital. Jurnal Studi Insania, 7(1), 20-34.

Aslan, Setiawan, A., \& Hifza. (2019). Peran Pendidikan dalam Merubah Karakter Masyarakat Dampak Akulturasi Budaya di Temajuk. FENOMENA: Jurnal Penelitian, 11(1), 11-30. https://doi.org/10.21093/fj.v11i1.1 403

Bass, B. M. (1990). Bass and Stogdill's Handbook of Leadership, 3rd Edition. Free Press.

Buchori, D. S. (2009). Sejarah politik islam (Cetakan Pertama). Pustaka Intermasa.
Damsar. (2011). Pengantar Sosiologi Pendidikan. Kencana.

Danim, S. (2003). Menjadi Komunitas Pembelajar ( Kepemimpinan Transformasional dalam Komunitas Organisasi Pembelajaran). Bumi Aksara.

Fatma Melati, F. (2013). Dinamika Perubahan Sosial Dan Budaya di Desa Kendalsari, Kecamatan Sumobito, Kabupaten Jombang. AntroUnairDotNet, 2(1), 291-297.

Fauzi, A. (2017). Kepemimpinan Kepala Madrasah Dalam Mengembangkan Lembaga Pendidikan Islam. Nidhomul Haq: Jurnal Manajemen Pendidikan Islam, 2(2), 42-53.

Fitriani, A. (2015). Gaya Kepemimpinan Perempuan. Jurnal TAPIs, 11(2), 124.

Hanifah Gunawan, Karim Suryadi dan Elly Malihah. (n.d.). Analisis Perubahan Sosial Budaya Masyarakat Desa Cihideung sebagai Desa Wisata. Sosietas, 5(2), 1-9.

Hendro. (2011). Dasar-dasar Kewirausahaan. Erlangga.

Hutagaluh, O., \& Aslan. (2019). Pemimpin dan Pengaruh Geo Politik Terhadap Lahirnya Sumber Daya Manusia Yang Berkarakter. Jurnal Studi Islam Lintas Negara, 1(2), 23-29. 
Idi, A. (2011). Sosiologi Pendidikan: Individu, Masyarakat dan Pendidikan, ed., Safarina. Rajawali Pers.

Ivancevich, dkk. (2007). Perilaku dan Manajemen Organisasi. Erlangga.

Kadir, A. (n.d.). Kepemimpinan Ulul Albab [Hasil Penelitian]. STAIN Sultan Qaimuddin Kendari.

Karim, M. (2010). Pemimpin Transformasional di Lembaga Pendidikan Islam. UIN Maliki Press.

Kartono, K. (1984). Pemimpin dan Kepemimpinan. Rajawali Press.

Kesuma, G. C. (2014). Pesantren dan Kepemimpinan Kiai. Jurnal Pendidikan Dan Pembelajaran Dasar, 1(1), 99-117.

Khoiri, N. (2016). Madrasah culture based transformational leadership model. Nadwa: Jurnal Pendidikan Islam, 10, 151-174.

Khotimah. (2014). Agama dan Civil Society. Ushulluddin, XXI(1), 121-132.

Kirgiz, A. (2014). Hedonism, A Consumer Disease Of The Modern Age: Gender And Hedonic Shopping In Turkey. Global Media, 4(8), 200-212.

Langgulung, H. (1991). Kreativitas dan Pendidikan Islam. Al-Husna.

Ma'arif, M. A., \& Rofiq, M. H. (2019). The model of character teacher: Phenomenology at Daruttaqwa Gresik Islamic Boarding School. Attarbiyah: Journal of Islamic Culture and Education, 3(2), 131-152. https://doi.org/10.18326/attarbiyah .v3i2.131-152

Mahmuddin. (2014). Kepemimpinan Dakwah. Jurnal Dakwah Tabligh, 15(2), 177-187.

Makmur, G. (2013). Pendidikan Politik Dalam al-Qur'an [Makalah S3]. IAIN Antasari.

Ma'sum, T. (2019). Persinggungan Kepemimpinan Transformational Dengan Kepemimpinan Visioner Dan Situasional. INTIZAM: Jurnal Manajemen Pendidikan Islam, 2(2), 84 106.

McClelland, D. (1987). Pengantar Kewirausahaan. Intermedia.

Moh. Padil \& Triyo Supriyatno. (2010). Sosiologi pendidikan. UIN-Maliki Press.

Mujiburrahman. (2015). Agama, Media Dan Imajinasi: Pandangan Sufisme Dan Ilmu Sosial Kontemporer (Cetakan 2). Antasari Press.

Mujiburrahman. (2016, March 28). Sendiri Bersama-sama (Ponsel). Banjarmasin Post.

http://banjarmasin.tribunnews.com /2016/03/28/sendiri-bersamasama-ponsel

Mujiburrahman. (2017). Agama Generasi Elektronik (Cetakan Pertama). Pustaka Pelajar. 
Mujiono, I. (2002). Kepemimpinan dan Keorganisasian. UII Press.

Nata, A. (2011). Metodologi Studi Islam. PT. Raja Grafindo Persada.

Noor, M. I. (2010). Teologi Dan Pembangunan (Sebuah Analisa Filosofis). Darussalam, 11(2), 55-68.

Nukman, I. (2014). Tantangan Kepemimpinan: Pengantar Menelusuri Konsep Kepemimpinan Indigenous. Jurnal Psikoislamika, 11(2), 12-16.

Parsons, T., \& Smelser, N. (2005). Economy and Society: A Study in the Integration of Economic and Social Theory. Routledge and Kegan Paul.

Piliang, Y. A. (2011). Dunia Yang Telah Diliipat: Tamasya Melampaui BatasBatas Kebudayaan. Matahari,.

Putri Ekasari dan Arya Hadi Dharmawan.

(2012). Dampak Sosial-Ekonomi Masuknya Pengaruh Internet Dalam

Kehidupan Remaja Di Pedesaan. Sosiologi Pedesaan, 6(1), 57-71.

Ramli, M. (2017). Manajemen dan Kepemimpinan Pesantren: Dinamika Kepemimpinan Kiai di Pesantren. Al Falah, XVII(32), 125162.

Retnowati. (2014). Agama, Konflik, Dan Integrasi Sosial. Analisa, 21(2), 189_ 200.
Rivai, V., \& Mulyadi, D. (2003). Kepemimpinan dan Perilaku Organisasi. Radja Grafindo Persada.

Rosana, E. (2011). Modernisasi dan perubahan sosial. Jurnal TAPIs, 7(1), 46-62.

Rosyad, A. M., \& Maarif, M. A. (2020). Paradigma Pendidikan Demokrasi Dan Pendidikan Islam Dalam Menghadapi Tantangan Globalisasi Di Indonesia. Nazhruna: Jurnal Pendidikan Islam, 3(1), 75-99. https://doi.org/10.31538/nzh.v3i1. 491

Setyadarmodjo, S. H. (2000). Organisasi Partai Politik dan Demokrasi. Masyarakat, Kebudayaan Dan Politik, XIII(1), 87-94.

Siswanto. (2007). Politik Dalam Organisasi (Suatu Tinjauan Menuju Etika Berpolitik). Manajemen Pelayanan Kesehatan, 10(4), 60-70.

Syafaruddin. (2005). Manajemen Lembaga Pendidikan Islam. Ciputat Press.

Syatibi, I. (2009). Kepemimpinan Perempuan di Pesantren. Al-Abwal, 2(1), 29-46.

Sztompka, P. (1993). Sociology Of Social Change. Oxford UK.

Teguh, dkk, M. (2001). Latihan Kepemimpinan Islam Tingkat Dasar [LKID]. UII Press.

Thomas J. Fararo. (2006). Talcott Parsons (1902-1979). Encyclopedia of Economic 
Nidhomul Haq, Vol 5 No 1 Tahun 2020

Sociology Edited by Jens Beckert and Milan.

Toffler, A. (1970). Future Shock. Bantam Books.

Toffler, A. (1980). The Third Wave. William Morrow and Company, INC.

Widodo, J. (n.d.). Kepemimpinan Pendidikan Transaksional dan Transformasional di SMK Non Teknik. Fakultas Ekonomi UNNES.

Xiong, Y. (2009). Social Change and Social Policy in China: National Adaptation to Global Challenge. Japanese Sociology, 18, 33-45.

Yulifar, L. (2010). Sosiologi dan Antripologi Pembangunan. Hand Book: Pendidikan dan Ilmu Pengetahuan Sosial.

Zamzam, Z. (2018). Syekh Muhammad Arsyad Al-Banjary: Sebagai Ulama Juru Da'wah Sejarab Penyiaran Islam di Kalimantan Abad 13 H/18 M dan Pengarubnya di Asia Tenggara. Antasari Press.

Zulkifli, A. R. (2016). Gaya Hidup Hedonisme Di Kalangan Mahasiswa Penerima Beasiswa Kaltim Cemerlang 2014 Di Fakultas Ilmu Sosial Dan Ilmu Politik Universitas Mulawarman. Sosiatri-Sosiologi, 4(1), 72-85. 